\title{
THE IMPACT OF TRANSFORMATIONAL LEADERSHIP TO TEAM PERFORMANCE
}

\author{
Yudi Mochamad \\ Ph.D scholar, Post Graduate School of Economics \\ Hasanuddin University \\ South Sulawesi, Indonesia \\ Djabir Hamzah \\ Professor of Economics, Post Graduate School of Economics \\ Hasanuddin University \\ South Sulawesi, Indonesia \\ Otto R. Payangan \\ Professor of Economics, Post Graduate School of Economics \\ Hasanuddin University \\ South Sulawesi, Indonesia \\ Nurdjanah Hamid \\ Ph.D of Economics, Post Graduate School of Economics \\ Hasanuddin University \\ South Sulawesi, Indonesia \\ DOI: 10.31364/SCIRJ/v7.i11.2019.P1119722 \\ http://dx.doi.org/10.31364/SCIRJ/v7.i11.2019.P1119722
}

\begin{abstract}
This study aims to determine and analyze the influence of transformational leadership style to team performance. This type of research is explanatory research. The approach used to analyze is a quantitative approach. This research was conducted at the Maintenance \& Utilities Department, PT Vale Indonesia (Tbk). The population in this study were all department leaders and employees as many as 567 people in several positions in Maintenance \& Utilities. The number of samples is 235 , with purposive sampling (purposive sampling) as a sampling technique. The analysis technique used in this study is regression analysis. The results showed that transformational leadership style variables have a positive and significant effect on team performance.
\end{abstract}

Index Terms - transformational leadership style, organizational, maintenance and team performance

\section{INTRODUCTION}

The development of knowledge in the field of human resource management is so rapid as a form of application and resolution of the complexity of problems that arise in organizations (Wooten, 2019 and Akarsu et al. 2018). The issue of performance is always a major concern for academics to get the best solution so that it helps the organization achieve its goals, vision and mission. Robbins \& Judge (2017) has explained the complexity of performance problems in the concept of organizational behavior both performance at the level of individuals, groups, and organizations.

Performance issues at the individual and organizational level have long been studied by various academics around the world, so that the literature / literacy on the topic is relatively easy to trace. While performance issues that specifically address the team are still relatively small compared to other performance issues. Some previous researchers sought to focus on examining the issue with various scientific arguments. Team performance is the responsibility between the team leader and its members, so that if the overall effectiveness of team performance is achieved it will facilitate the organization to achieve superior and superior performance (Doorewaard, et al. 2002; Chan et al. 2003; Higgs et al. 2005; \& Wood et al. 2011).

Business organizations have given more attention to efforts to improve team performance in response to management efforts in facing dynamic and competitive business competition. Study of Han et al. (2016); and Lippert \& Dulewicz (2018) state that 
organizations need reliable team performance in response to global change. Study of Ceschi et al. (2014) found that improving team performance as a management effort to improve the quality of learning and effectiveness in the organization's internal strategic decision making.

Teams are units of two or more individuals who interact interdependently to achieve common goals (Bell, 2007). In general, the team is a model that is better than the individual in solving problems, making decisions, improving quality, and improving joint performance and organization (Hunt, 1999). Hunt (1999) also reported that in 1994, 91\% of Fortune 1000 companies used special teams to solve problems and two thirds were permanent teams. This value is a $33 \%$ increase from 1987. In line with this description, this study focuses on team performance as a working group within the organization.

Leadership theory states that transformative leadership will be able to move subordinates to achieve goals. Empirical results show that transformative leadership has a positive effect on organizational citizenship performance and behavior (Morgeson et al., 2010; Resick et al. 2009). Transformative leadership style is better than transactional leadership style which only has an exception pattern and contingent reward. Transformative style emphasizes vision to be reached by subordinates along with individualized considerations, intellectual stimulation, and inspirational motivation. He did not just give up a task and see the results and then give a response.

The different findings and theories that explain it related to the relationship of transformational leadership and performance provide a second research gap as well as a theoretical gap in this study. Transformative leadership variables have never been tested together with the team process framework from LePine et al. (2008). This provides a third research gap that provides new research opportunities that combine these three variables as predictors for team performance.

\section{LITERATURE REVIEW}

\subsection{Leadership Style}

Leadership style as a form of behavior pattern will have a number of background factors that determine why a leader uses a certain style compared to other styles. The basic factors commonly used are demographic factors such as gender, age, and education level (Barbuto et al., 2007). These factors are known to determine the leadership style of the full range leadership model. Women in general tend to be more transformational than men (Eagly \& Johnson, 1990). Older leaders are also more likely to be transformational than young leaders (Eagly et al. 2003). Similarly, leaders with higher education prefer to be transformative rather than transactional (Barbuto et al, 2007).

\subsection{Team Performance}

Team performance is how well a team reaches its goals or mission (Willbanks, 2003: 10). Various indicators have been put forward by researchers to measure team performance. Campion, Medsker, \& Higgs (1993) use productivity, employee satisfaction, and manager's judgment as indicators of team performance. Meanwhile, Cohen, Ledford, \& Spreitzer (1996), use output quality and quantity, team members' attitudes toward work quality, and behavioral outputs are indicators of team performance.

\section{RESEARCH METHODS}

The object of this research was carried out in the Department of Maintenance \& Utilities, PT Vale Indonesia (Tbk) with the technique used was the survey method. This type of research in terms of research objectives is explanatory research. The population in this study were all department leaders and employees as many as 567 people in several positions in Maintenance \& Utilities. These positions include (a) Utilities Maintenance; (b) Construction Services \& Town Maintenance; (c) Maintenance Engineering; (d) Process Plant Maintenance; (e) Central Maintenance; and (f) Reliability \& Planning. This study uses 22 indicators so that the sample requirements are 110. In this study using 235 samples exceeded the required sample size. This study used a survey method by distributing closed questionnaires to identify respondents' perceptions and assessments of the research variables. The analysis technique in this study is linear regression to explain the influence. 


\section{RESULTS AND DISCUSSION}

\subsection{Characteristics of Respondents}

Based on the results of distributing 300 questionnaires, only 196 valid questionnaires to be tested further. Based on the results of questionnaires obtained results in the form of characteristics of respondents. The characteristics of the respondents are descriptions of identities that explain age, gender, work period, last education, work unit, and position / position as follows.

Table 1. Results of respondents' characteristics

\begin{tabular}{|c|c|c|c|}
\hline \multirow{2}{*}{ Respondents are based } & \multirow{2}{*}{ Classification } & \multicolumn{2}{|c|}{ Respondents } \\
\hline & & $\mathbf{F}$ & $\%$ \\
\hline \multirow[t]{3}{*}{ Age } & $\leq 30$ years & 64 & 32,65 \\
\hline & $\geq 31$ years & 132 & 67,35 \\
\hline & Total & 196 & 100,0 \\
\hline \multirow[t]{3}{*}{ Gender } & Man & 183 & 93,37 \\
\hline & Women & 13 & 6,63 \\
\hline & Total & 196 & 100,0 \\
\hline \multirow[t]{3}{*}{ Years of service } & $\leq 5$ years & 2 & 1,02 \\
\hline & $\geq 6$ years & 194 & 98,98 \\
\hline & Total & 196 & 100,0 \\
\hline \multirow[t]{4}{*}{ Last education } & High school / equivalent & 0 & 0 \\
\hline & Diploma / Academy & 55 & 28,06 \\
\hline & Strata $(\mathrm{S} 1, \mathrm{~S} 2$, or S3) & 141 & 71,94 \\
\hline & Total & 196 & 100,0 \\
\hline \multirow[t]{7}{*}{ Work unit } & Utilities Maintenance & 22 & 11,22 \\
\hline & $\begin{array}{c}\text { Construction Services \& Town } \\
\text { Maintenance }\end{array}$ & 49 & 25,00 \\
\hline & Maintenance Engineering & 10 & 5,10 \\
\hline & Process Plant Maintenance & 68 & 34,69 \\
\hline & Central Maintenance & 36 & 18,37 \\
\hline & Reliability \& Planning & 11 & 5,61 \\
\hline & Total & 196 & 100,0 \\
\hline \multirow[t]{4}{*}{ Position } & Head of division / department & 6 & 3,61 \\
\hline & Supervisor & 24 & 12,24 \\
\hline & Employee & 166 & 84,69 \\
\hline & Total & 196 & 100,0 \\
\hline
\end{tabular}

Respondents aged $\leqslant 30$ years were 32.65 percent ( 64 people), the age of respondents $\geqslant 31$ years was 67.35 percent (132 people). This shows that the respondents are dominated by productive age employees. The sex characteristics indicate that the duties and workload of PT Vale's maintenance department are more suitable for male employees than for women. Referring to the tenure category shows that the majority of respondents have qualified skills, experience, and competencies, this is based on the duration of their time of more than 6 years working. The most recent level of education is the bachelor who is relevant between the educational background and the respondent's occupation. The work unit / department that contributed the most was the process plant maintenance with the number of respondents as many as 68 people (34.69 percent). The results of the respondent's description indicate that the majority of respondents are employees, while the head of department is only 6 people. 


\subsection{Results of the Regression Analysis}

Regression analysis is an analytical tool that aims to determine the direction of the relationship between independent variable (transformational leadership) and the dependent variable (team performance) whether each independent variable is positively or negatively related and to predict the value of the dependent variable if the independent variable experiences increase or decrease. If the regression coefficient is significant on probability 0.05 , the independent variable has a significant effect on the dependent variable. The results of the calculation of regression models using SPSS 22.0 software show the following results:

Table 1 Results of Regression

\begin{tabular}{lllll}
\hline Variable & $\begin{array}{l}\text { Coefficient } \\
\text { Regression }(\boldsymbol{\beta})\end{array}$ & $\begin{array}{l}\text { Standar } \\
\text { Error }\end{array}$ & t & Prob. \\
\hline Constant & 1.016 & 0.215 & 4.724 & 0.000 \\
Transformational leadership & 0.730 & 0.053 & 13.653 & 0.000 \\
$\mathrm{~F}=186.412$ & & & & \\
Sig $=0.000$ & & & \\
$\mathrm{R}^{2}=0.655$ & & & \\
$\mathrm{R}=0.810$ & & & \\
Adjusted R Square $=0.652$ & & & \\
\hline
\end{tabular}

Based on the regression equation above, the regression coefficient of transformational leadership variable is 0.7305 . The coefficient indicates a positive and significant relationship between transformational leadership variables on team performance. This can be interpreted by improving the quality of transformational leadership which will have an impact on improving team performance. Based on the SPSS appendix, the adjusted R square value is 0.652 , this means 65.2 percent of the performance of the state civil apparatus can be explained by variations in transformational leadership variables and organizational commitment, while the rest are explained by other variables.

\section{CONCLUDING REMARKS}

Based on direct influence, there is an influence between transformational leadership style on team processes. Transformational leadership style that is applied consistently will have an impact on improving team processes. The advantages of implementing transformational leadership styles in maintenance departments at PT Vale Indonesia Tbk can be observed through increasing individualized consideration capabilities based on respondents' assessments. The results of the study have proven that the quality of transformational leadership style influences team processes, but efforts are needed to improve the quality of the leadership style by moving all organizational resources, both the raw material production resources, financial resources, equipment, and other sources with efficient management. to achieve the company's strategic goals.

\section{REFERENCES}

[1] Akarsu, O., Mehmet G., \& S. Yildirim (2018). Listening to the organization: change evaluation with discourse analysis. Journal of Organizational Change Management, Vol. 31 Issue: 5, pp.1040-1053.

[2] Barbuto, J. E. J., Fritz, S., Matkin, G. S., \& Marx, D. B (2007). Effects of Gender, Education, and Age upon Leaders ' Use of Influence Tactics and Full Range Leadership Behaviors Effects of Gender, Education, and Age upon Leaders ' Use of In fl uence Tactics and Full Range Leadership Behaviors. Sex Roles, 56, 71-83.

[3] Bell, S. T (2007). Deep-level composition variables as predictors of team performance: A meta-analysis. Journal of Applied Psychology, 92(3), 595-615.

[4] Campion, M. A., Medsker, G. J., \& Higgs, A. C. (1993). Relations between work group characteristics and effectiveness: Impications for designing effective work groups. Personnel Psychology.

[5] Chan, C.C.A., C. Pearson., \& L. Entrekin (2003). Examining the effects of internal and external team learning on team performance. Team Performance Management: An International Journal, Vol. 9 Issue: 7/8, pp.174-181.

[6] Ceschi, A., K. Dorofeeva., \& R. Sartori (2014). Studying teamwork and team climate by using a business simulation: How communication and innovation can improve group learning and decision-making performance. European Journal of Training and Development, Vol. 38 Issue: 3, pp.211-230. 
[7] Cohen, S. G., Ledford, G. E., \& Spreitzer, G. M. (1996). A predictive model of self-managing work team effectiveness. Human Relations, 49(5), 643-676.

[8] Doorewaard, Hans., Geert Van Hootegem., \& R. Huys (2002). Team responsibility structure and team performance. Personnel Review, Vol. 31 Issue: 3, pp.356-370.

[9] Eagly, A. H., \& Johnson, B. T (1990). Gender and Leadership Style : A Meta-Analysis Gender and Leadership Style : A MetaAnalysis. Psychological Bulletin, 108(2), 233-256.

[10] Eagly, A. H., Johannesen-schmidt, M. C., \& van Engen, M (2003). Transformational , Transactional , and Laissez-Faire Leadership Styles : A Meta-Analysis Comparing Women and Men. Psychological Bulletin, 129(4), 569-591.

[11] Han, H., W. Kim., Chul Jeong (2016). Workplace fun for better team performance: focus on frontline hotel employees. International Journal of Contemporary Hospitality Management, Vol. 28 Issue: 7, pp.1391-1416.

[12] Higgs, M., U. Plewnia., \& J. Ploch (2005). Influence of team composition and task complexity on team performance. Team Performance Management: An International Journal, Vol. 11 Issue: 7/8, pp.227-250.

[13] Hunt, D. H. (1999). A System Approach to Team Performance Measurement. Massachusetts Institute of Technology.

[14] LePine, J. A., Piccolo, R. F., Jackson, C. L., Mathieu, J. E., \& Saul, J. R (2008). A meta-analysis of teamwork processes: Tests of a multidimensional model and relationships with team effectiveness criteria. Personnel Psychology, 61, $273-307$.

[15] Lippert, H., \& V. Dulewicz (2018). A profile of high-performing global virtual teams. Team Performance Management: An International Journal, Vol. 24 Issue: 3/4, pp.169-185.

[16] Morgeson, F. P., DeRue, D. S., \& Karam, E. P (2010). Leadership in teams: A functional approach to understanding leadership structures and processes. Journal of Management (Vol. 36).

[17] Resick, C. J., Whitman, D. S., Weingarden, S. M., \& Hiller, N. J (2009). The Bright-Side and Dark-Side of CEO Personality: Examining Core Self-Evaluations, Narcissism, Transformational Leadership, and Strategic Influence. Journal of Applied Psychology, 94(6), 1365.

[18] Robbins, S.P., \& Tim Judge (2017). Organizational Behavior. Edition $17^{\text {th }}$. Boston, Pearson.

[19] Willbanks, K. D (2003). Relationship of Team Training Components to Perceptions of Team Performance. University of North Texas.

[20] Wood, S., G. Michaelides., \& C. Thomson (2011). Team approach, idea generation, conflict and performance. Team Performance Management: An International Journal, Vol. 17 Issue: 7/8, pp.382-404.

[21] Wood, S., G. Michaelides., \& C. Thomson (2011). Team approach, idea generation, conflict and performance. Team Performance Management: An International Journal, Vol. 17 Issue: 7/8, pp.382-404.

[22] Wooten, M.E (2019). Race, Organizations, and the Organizing Process, in Melissa E. Wooten (ed.) Race, Organizations, and the Organizing Process (Research in the Sociology of Organizations, Volume 60) Emerald Publishing Limited, pp.1 - 14 